\title{
HUBUNGAN ANTARA KEJADIAN OSTEOARTRITIS DENGAN OBESITAS YANG DIUKUR DENGAN METODE PENGUKURAN BMI
}

\author{
Agus Suseno \\ Puskesmas Sandul, Seruyan Kalimantan Tengah \\ E-mail: wirasasmita09@gmail.com
}

\begin{abstract}
ABSTRAK
Hubungan Antara Kejadian Osteoartritis Dengan Obesitas Yang Diukur Dengan Metode Pengukuran BMI. Latar Belakang. Badan Kesehatan Dunia (WHO) telah menyatakan bahwa obesitas telah menjadi epidemi dunia. Saat ini prevalensi penderitanya tiap tahun semakin meningkat. Obesitas merupakan salah satu faktor resiko osteoartritis, ditandai dengan kerusakan pada tulang rawan sendi yang berakhir dengan kerusakan ke seluruh sendi. Hingga kini belum ada obat yang pasti untuk menanggulangi penyakit osteoartritis. Pengobatan yang dilakukan selama ini hanya untuk menghilangkan rasa nyerinya saja. Tujuan Penelitian. Untuk mengetahui adanya hubungan antara kejadian osteoartritis pada penderita obesitas dengan menggunakan metode BMI. Metodologi Penelitian. Analitik observasional dengan pendekatan secara cross sectional. Sampel diambil secara random sampling melalui rekam medik rawat jalan bagian Rheumatologi Rumah Sakit Swasta Kota Malang periode Januari - Desember 2006. Untuk menentukan adanya hubungan osteoartritis dengan obesitas dilakukan uji hipotesis Chi Square dengan nilai signifikasi (p) lebih kecil dari alpha 0.05. Hasil Penelitian. Dari 125 sampel penelitian didapatkan 70,4\% wanita dan prevalensi osteoartritis dengan obesitas $58,4 \%$. Hasil uji chi square didapatkan adanya hubungan antara kejadian osteoartritis dengan obesitas menggunakan metode pengukuran body mass index yang ditunjukkan dengan nilai signifikasi (p) 0.035. Kesimpulan. Didapatkan hubungan yang bermakna antara kejadian osteoarthritis dengan obesitas menggunakan metode pengukuran body mass index.
\end{abstract}

\section{ABSTRACT}

The Relation Between Osteoarthritis Occurrence and Obesity Using Measurement of BMI Method. Background. WHO have been declared obesity become World's epidemic. Recently its prevalence increases. Obesity can cause osteoarthritis. It is characterized by damage on cartilage joint leading to damage on entire joint. There has not been medicine to cure osteoarthritis. The medication is just for relieving the pain. Objective of Research. To know whether there is relation of osteoarthritis occurrence on person with obesity using BMI method. Research Method. Observational analytic with cross - sectional approach. Sample was taken by random sampling through medical record treatment in Rheumatology department of Private Hospital in Malang on January - December 2006. To determine the existence relation of osteoarthritis with obesity require to test of hypothesis of Chi Square with value of signification (p) smaller than alpha 0.05. Result of the Research. From 125 research sample got by $70.4 \%$ and woman of prevalence osteoarthritis with obesity 58,4\%. Result of test of chi square got by the existence of relation between occurence of osteoarthritis with obesity use method measurement of index mass body posed at with value of signification (p) 0.035. Conclusion. There is significant relation between osteoarthritis occurance and obesity using body mass index.

Key words: Osteoarthritis - Obesity - BMI

\section{PENDAHULUANI}

Obesitas merupakan suatu penyakit multifaktorial, yang terjadi akibat akumulasi jaringan lemak berlebihan, sehingga dapat mengganggu kesehatan. Obesitas terjadi bila besar dan jumlah sel lemak bertambah pada tubuh seseorang. Bila seseorang bertambah berat badannya maka ukuran sel lemak akan bertambah besar dan jumlahnya bertambah banyak (Sugondo, 2006).Berbagai kalangan masyarakat masih berpendapat bahwa, gemuk merupakan suatu kebanggaan dan merupakan kriteria untuk mengukur kesuburan dan kemakmuran suatu kehidupan, sehingga pada saat ini masih banyak orang kerap tak memperdulikan tubuhnya menjadi gemuk dan mempertahankannya sesuai dengan status sosialnya (Witjaksono, 2002).
Badan Kesehatan Dunia (WHO) telah menyatakan bahwa obesitas telah menjadi masalah epidemi dunia (Basha, 2007). Lebih dari satu miliar penduduk dunia mengalami kelebihan berat badan (obesitas) terutama di negara yang maju. Bahkan, saat ini prevalensi penderitanya tiap tahun semakin meningkat. Penyakit yang dipicu oleh obesitas adalah sindroma metabolik dengan resiko penyakit kardiovaskular, gangguan pernapasan, osteoartritis, gangguan hormonal, peningkatan asam urat (gout), kanker, diabetes, dan strok (Wed, 2004).

Obesitas meningkat sesuai dengan bertambahnya usia, seperti yang ditunjukkan di Amerika Serikat, dimana 20\% laki-laki dan $40 \%$ wanita usia pertengahan menderita 
kegemukan. Pada tahun 2004, penelitian yang dilakukan oleh Himpunan Studi Obesitas Indonesia (HISOBI) mendapatkan angka prevalensi obesitas (BMI $30 \mathrm{~kg} / \mathrm{m} 2$ ) $9,16 \%$ pada pria dan $11,02 \%$ pada wanita Bila tren seperti sekarang ini berjalan terus, maka tahun 2025 tidak mustahil $40 \%$ dari penduduk indonesia akan menyandang gelar "obese". Saat ini kita hidup pada masa berat badan lebih (BMI 23 - 24,9) dan obesitas (BMI 25 - 30) sudah menjadi suatu epidemi, dengan dugaan peningkatan prevalensi obesitas akan mencapai $50 \%$ pada tahun 2025 bagi negaranegara maju (Depkes RI, 2005).

Pencegahan obesitas memberi manfaat tidak saja bagi kesehatan sendi, tetapi untuk penyakit-penyakit lainnya. Mereka yang berberat badan lebih mempunyai prevalensi osteoartritis lutut yang tinggi. Pada mereka yang obese, setiap penurunan berat badan lima kilogram akan mengurangi resiko osteoartritis sebesar 50\% (Setiyohadi $\mathrm{dkk}, 2006)$.

Dari uraian diatas maka peneliti ingin mengetahui bagaimanakah hubungan obesitas dengan kejadian osteoartritis menggunakan metode body mass index (BMI) sehubungan dengan prevalensi osteoartritis lutut yang tinggi pada mereka yang berberat badan lebih sehingga diperlukan pengolahan data hasil penelitian untuk membuktikan.

\section{BAHAN DAN METODE}

Rancangan penelitian yang dipergunakan dalam penelitian ini adalah analitik observasional dengan pendekatan secara cross sectional.

\section{Populasi dan sampel}

Populasi penelitian ini adalah pasien rawat jalan bagian Rheumatologi Rumah Sakit Swasta Kota Malang periode Januari - Desember 2006. Sampel penelitian ini adalah pasien yang menjalani pengobatan lanjutan atau kontrol kesehatan.

Kriteria inklusi dan eksklusi

Kriteria inklusi :

- Pasien bagian rheumatologi tersebut di atas yang melakukan pengobatan lanjutan atau kontrol kesehatan.

- Pasien bagian rheumatologi yang berumur 40-60 tahun. Kriteria ekslusi :

Pasien osteoartritis yang diabetes melitus

Pasien osteoartritis yang hipertensi

Pasien osteoartritis oleh karena trauma atau cedera

Teknik pengambilan sampel

Teknik pengambilan sampel pada penelitian ini dengan menggunakan metode Simple Random Sampling yaitu cara pemilihan sampel dimana anggota dari populasi dipilih satu persatu secara random (semua mendapatkan kesempatan yang sama untuk dipilih) dimana jika sudah dipilih tidak dapat dipilih lagi, dan besar sampel dihitung dengan menggunakan rumus Slovin. Rumus Slovin adalah rumus yang digunakan untuk menghitung estimasi proporsi minimum sampel yang dibutuhkan, yang dapat mewakili populasi total.
Menghitung besarnya sampel dengan rumus Slovin :

$$
\begin{aligned}
& \mathrm{n}=\mathrm{N} \\
& \mathrm{N} \cdot \mathrm{d} 2+1
\end{aligned}
$$

Keterangan :

d : Derajat kesalahan (ketetapan : 0,01)

$\mathrm{N}$ : Besarnya populasi

n : Besarnya sampel. (Sastroasmoro, 1995)

Berdasar rumus Slovin, maka proporsi minimum sampel yang dibutuhkan:

$$
\mathbf{n}=\frac{\mathbf{N}}{\mathrm{N} \cdot \mathbf{d}^{2}+1}=\frac{907]}{907 \cdot(0,10)^{2}+1}=\frac{907}{10,07}=\mathbf{9 0 , 0 6}
$$

Hasil $n=90,06$--- dibulatkan menjadi 90 orang. Jadi besar sampel minimal untuk penelitian ini adalah 90 pasien.

Lokasi dan waktu

Lokasi penelitian ini adalah di RS Swasta Kota Malang. Waktu pelaksanaan penelitian adalah pada bulan MeiJuni 2008

Variabel penelitian

Variabel bebas yang digunakan dalam penelitian ini adalah obesitas. Variabel tergantung dalam penelitian ini adalah kejadian osteoartritis.

\section{Definisi operasional}

1. Osteoartritis adalah penyakit sendi yang karakteristik dengan menipisnya rawan sendi secara progresif, disertai dengan pembentukan tulang baru pada trabekula subkondral dan terbentuknya rawan sendi dan tulang baru pada tepi sendi (osteofit) (Isbagio, 2006). Predileksi Osteoartritis terdapat pada sendi-sendi tertentu antara lain carpometacarpal I, metatarsophalangeal I, sendi apofiseal tulang belakang, lutut (genu), paha, siku, pergelangan tangan, glenohumeral, dan pergelangan kaki. Untuk diagnosa osteoartritis dengan melihat hasil radiologi (Soeroso dkk, 2006).

2. Body Mass Index (BMI), merupakan suatu pengukuran yang menunjukkan hubungan antara berat badan dan tinggi badan. BMI merupakan suatu rumus matematika dimana berat badan seseorang (dalam $\mathrm{kg}$ ) dibagi dengan

3. Seseorang dengan BMI 30 atau lebih dikatakan mengalami obesitas, BMI yang tinggi merupakan suatu ramalan kematian karena penyakit jantung, diabetes, kanker, tekanan darah tinggi (hipertensi) dan osteoartritis juga merupakan akibat dari overweight dan obesitas yang sering ditemukan pada dewasa.

\section{Instrumen penelitian}

Instrumen yang digunakan adalah catatan Rekam Medik pasien osteoartritis yang obesitas yang melakukan pemeriksaan di bagian Rheumatologi RS Swasta Kota Malang periode Januari-Desember 2006.

\section{Teknik pengumpulan data}

Data diperoleh dari data sekunder yaitu Rekam Medik pasien yang melakukan pemeriksaan di bagian Rheumatologi RS Swasta Kota Malang.

\section{Analisa data}

Data rekam medik yang didapatkan, dikelompokkan menjadi 4 kelompok. Kelompok I (osteoartritis (+), obesitas $(+)$ ), kelompok II (osteoartritis (+),obesitas (-)), kelompok 
III (osteoartritis (-), obesitas (+)), kelompok IV (osteoartritis $(-)$, obesitas $(-))$. Data tersebut dianalisa dengan menggunakan statistik deskriptif dan disajikan dalam bentuk tabel frekuensi distribusi. Keterkaitan antara pasien yang osteoartritis disertai obesitas dicari melalui uji statistik Chi Square dengan derajat kepercayaan $95 \%, \alpha=0.05$, bermakna bila $\mathrm{p}<0.05$ dengan menggunakan program SPSS for windows versi 11.00 dan disajikan dalam bentuk tabel.

\section{Alur Penelitian}

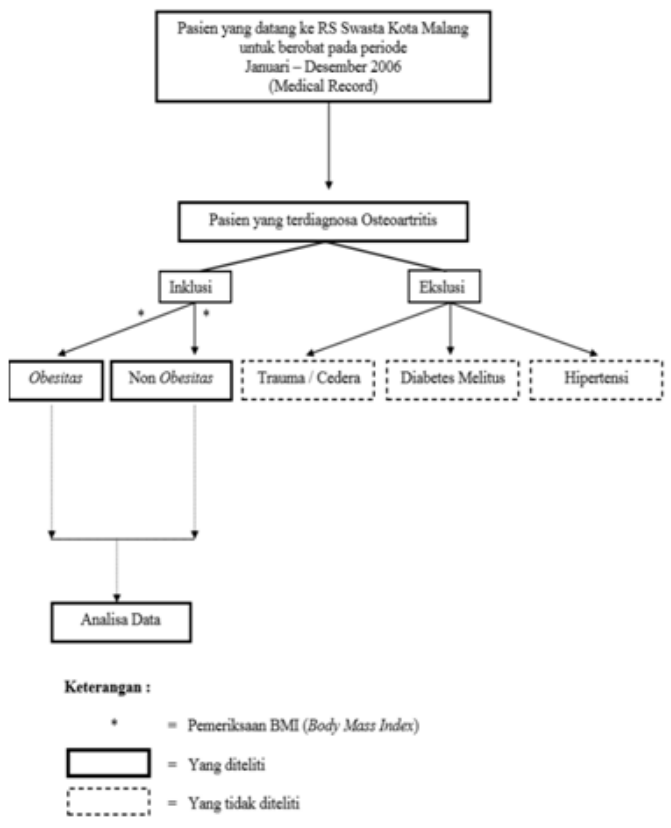

Gambar 1. Alur Penelitian

Penelitian ini dilakukan dengan mengambil data pasien Osteoartritis yang datang ke RS Swasta Kota Malang untuk berobat pada periode Januari- Desember 2006 melalui Rekam medis. Kemudian dilakukan penyaringan data yang sesuai dengan kriteria inklusi. Pada pasien yang memenuhi kriteria inklusi dilakukan pemeriksaan BMI (Body Mass Index) dan dikategorikan menjadi Pasien dengan Obesitas dan Pasien Non-Obesitas yang kemudian dilakukan analisa data pada data pasien tersebut.

\section{HASIL PENELITIAN DAN ANALISIS PENELITIAN}

Berdasarkan hasil penelitian yang dilakukan terhadap pasien rawat jalan yang datang keRumah SakitSwasta bagian Rheumatologi periode Januari -Desember 2006 untuk menjalanipengobatan lanjutan atau kontrol kesehatan, didapatkan data total populasi pasien bagianrheumatologi adalah 907 pasien. Besar sampel dihitung dengan menggunakan rumus Slovin.Didapatkan sampel 125 pasien bagian rheumatologi (dari jumlah populasi total adalah907 pasien). Dimana jumlah 125 sampel tersebut sudah memenuhi kriteria - kriteria inklusi yang ditetapkan oleh peneliti untuk penelitian ini, dan hal ini dilakukan dengan tujuan untuk mengetahui adanya hubungan antara kejadian osteoartritis pada penderita obesitas denganmenggunakan metode BMI.

\section{Data Umum Demografi Responden}

Analisis deskriptif ini dimaksudkan untuk menggambarkan distribusi dari karakteristik atau demografi responden. Berdasarkan hasil survey untuk memberikan gambaran secara umum mengenai karakteristik para responden dalam penelitian ini, diperoleh informasi mengenai usia, jenis kelamin mereka. Hasil rekapitulasi distribusi frekuensi yang terkumpul dari kuisioner tentang karakteristik responden tersebut dapat dilihat pada tabel berikut.

\section{Deskripsi Karakteristik Usia Pasien}

Data mengenai usia pasien bagian rheumatologi yang menjalani pengobatan lanjutan ataukontrol kesehatan didapatkan bahwa responden yang berusia antara 40-45 tahun ada sebanyak 21orang (16.8\%), 23 orang (18.4\%) berusia antara 46-50 tahun, 37 orang $(29.6 \%)$ berusia antara5155 tahun sedangkan 44 orang $(35.2 \%)$ berusia 56-60 tahun.

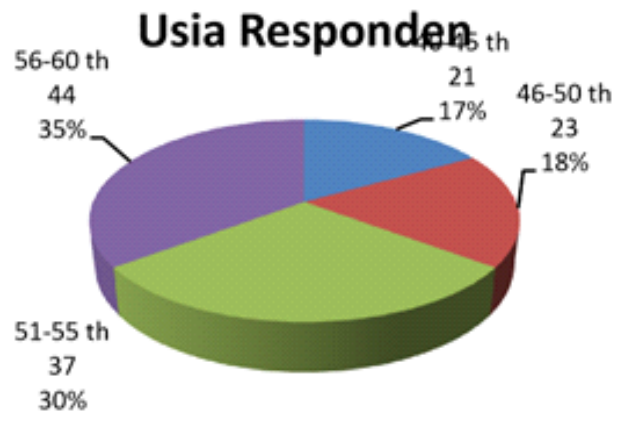

Gambar 2. Grafik Usia Responden

\section{Deskripsi Karakteristik Jenis kelamin Responden}

Untuk jenis kelamin para pasien bagian rheumatologi yang menjalani pengobatan lanjutan atau kontrol kesehatan, berdasarkan hasil penelitian dapat disajikan sebagai berikut: $40-45$ th $2117 \%$; 46-50 th $2318 \%$; 51-55 th $3730 \%$; 56-60 th $4435 \%$

\section{Usia Responden}

Tabel 1. Distribusi Karakteristik Responden Berdasarkan Jenis Kelamin

\begin{tabular}{|c|c|c|}
\hline Jenis kelamin & Frekuensi & Persentase (\%) \\
\hline Laki-laki & 37 & $29.6 \%$ \\
Perempuan & 88 & $70.4 \%$ \\
\hline Total & 125 & $100 \%$ \\
\hline
\end{tabular}

Dari hasil penelitian diketahui bahwa dari 125 orang pasien bagian rheumatologi yang menjalani pengobatan lanjutan atau kontrol kesehatan, didapatkan 37 orang (29.6\%) merupakan pasien laki-laki, sedangkan $70.4 \%$ responden lainnya merupakan pasien perempuan. Jadi penderita paling banyak dari kaum wanita. Adapun karakteristik responden tersebut dapat digambarkan dalam bentuk grafik sebagai berikut. 


\section{Jenis Kelamin}

\section{Responden}

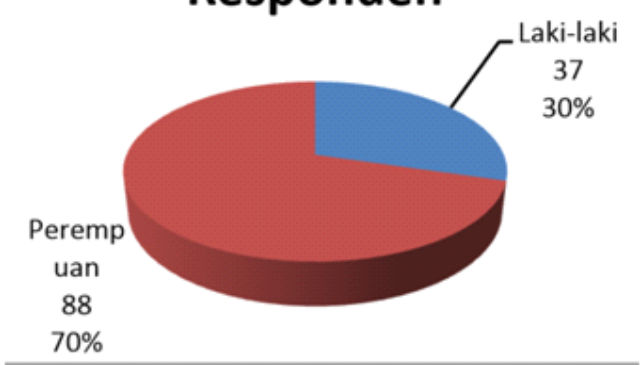

Gambar 3. Grafik Jenis Kelamin Responden

\section{Data Khusus}

Sebelum melakukan analisa lebih lanjut mengenai hubungan antara kejadian osteoartritis dengan obesitas menggunakan metode pengukuran BMI, maka terlebih dahulu dilakukan analisa deskriptif dengan maksud untuk mendeskripsikan distribusi frekuensi jawaban responden berdasarkan kuisioner yang disebarkan. Hasil distribusi frekuensi dari 125 orang pasien bagian Laki-laki 37 30\%; Peremp uan $8870 \%$;

\section{Jenis Kelamin Responden}

Rheumatologi yang menjalani pengobatan lanjutan atau kontrol kesehatan yang dijadikan sebagai responden dalam penelitian ini dapat dilihat selengkapnya pada lampiran hasil analisis data. Berikut ini merupakan paparan secara deskriptif mengenai variabel obesitas berdasarkan metode pengukuran BMI dengan kejadian osteoartritis berdasarkan jawaban responden.

\section{Obesitas}

Dari hasil penelitian terhadap 125 orang pasien bagian rheumatologi yang menjalani pengobatan lanjutan atau kontrol kesehatan didapatkan 40 orang (32\%) yang mempunyai hasil pengukuran BMI tergolong non obesitas, dan 85 orang $(68 \%)$ pasien mempunyai hasil pengukuran BMI tergolong Obesitas. Hal ini juga dapat digambarkan dalam bentuk grafik sebagai berikut.

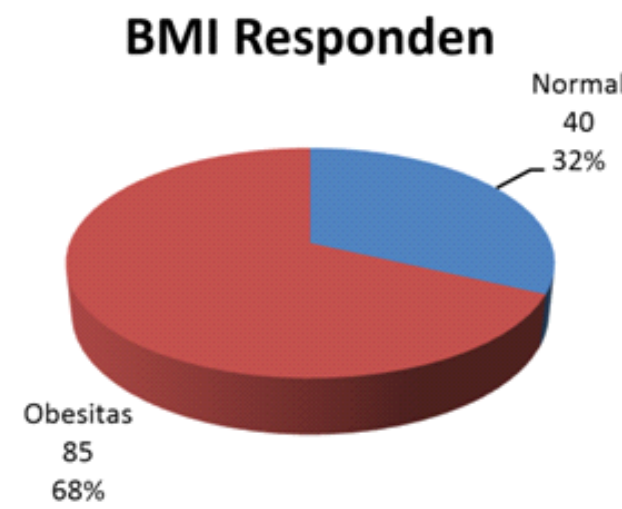

Gambar 4. Distribusi Frekuensi Hasil Pengukuran BMI Responden
Berdasarkan gambar di atas menunjukkan bahwa pasien bagian rheumatologi yang menjalani pengobatan lanjutan atau kontrol kesehatan lebih banyak yang mempunyai hasil pengukuran BMI tergolong Obesitas.

\section{Kejadian Osteoartritis}

Dari hasil penelitian terhadap 125 orang pasien bagian rheumatologi yang menjalani pengobatan lanjutan atau kontrol kesehatan didapatkan 24 orang (19.2\%) yang tidak terkena osteoartritis, dan 101 orang pasien (80.8\%) yang terkena osteoartritis. Hal ini juga dapat digambarkan dalam bentuk grafik sebagai berikut. Normal $4032 \%$; Obesitas 85 $68 \%$

\section{Frekuensi} Kejadian

\section{Osteoartritis}

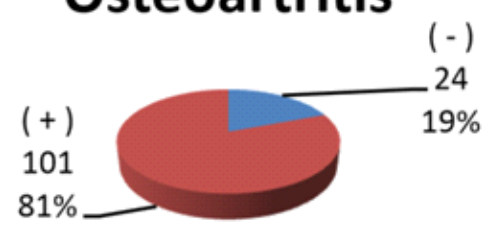

Gambar 5. Distribusi Frekuensi Kejadian Osteoartritis

Berdasarkan gambar di atas menunjukkan bahwa pasien bagian rheumatologi yang menjalani pengobatan lanjutan atau kontrol kesehatan lebih banyak yang terkena osteoartritis.

\section{Hubungan Antara Kejadian Osteoartritis Dengan Obesitas}

Untuk mengetahui ada atau tidaknya hubungan antara kejadian osteoartritis dengan obesitas menggunakan metode pengukuran BMI, maka perlu dibentuk tabulasi silang (crosstabs) yang dapat menggambarkan penyebaran data secara lebih terinci, sebagaimana disajikan pada tabel berikut.

\section{Tabel 2. Tabulasi Silang Hubungan Antara Kejadian Osteoartritis Dengan Obesitas Menggunakan Metode Pengukuran BMI Osteoartritis * Obesitas Crosstabulation Obesitas}

\begin{tabular}{|c|c|c|c|c|}
\hline & & \multicolumn{2}{|c|}{ Obesitas } & \multirow[t]{2}{*}{ Total } \\
\hline & & - & + & \\
\hline \multirow[t]{4}{*}{ Osteoartritis } & - Count & 12 & 12 & 24 \\
\hline & $\%$ within Obesitas & $9.6 \%$ & $9.6 \%$ & $19.2 \%$ \\
\hline & F Count & 28 & 73 & 101 \\
\hline & $\%$ within Obesitas & $22.4 \%$ & $58.4 \%$ & $80.8 \%$ \\
\hline \multirow[t]{2}{*}{ Total } & Count & 40 & 85 & 125 \\
\hline & $\%$ of Total & $32 \%$ & $68 \%$ & $100 \%$ \\
\hline
\end{tabular}

Pada tabel diatas terlihat bahwa pasien yang tergolong non obesitas yang tidak terkena osteoartritis didapatkan 12 orang $(9.6 \%)$, namun sebaliknya ada 28 orang $(22.4 \%)$ yang ( - ) 24 19\%( + ) 101 81\%justru terkena osteoartritis. Sedangkan pasien yang tergolong obesitas yang terkena osteoartritis didapatkan 73 orang (58.4\%), namun sebaliknya ada 12 orang $(9.6 \%)$ yang justru tidak terkena osteoartritis. Hasil Analisa Dengan Menggunakan Uji Chi-Square Selanjutnya, untuk menguji adanya hubungan antara kejadian osteoartritis dengan obesitas menggunakan metode pengukuran BMI, maka digunakan uji chi-Square (c2) sebagai test independency. 
Tabel 3. Perhitungan Manual Uji Chi-Square

\begin{tabular}{|c|c|c|c|c|c|}
\hline $\begin{array}{c}\text { Obesitas dengan } \\
\text { osteoartritis }\end{array}$ & $\mathrm{Oi}$ & $\mathrm{Ei}$ & $\mathrm{Oi}-\mathrm{Ei}$ & $(\mathrm{Oi}-\mathrm{Ei})^{2}$ & $\chi^{2}=\frac{(\mathrm{Oi}-\mathrm{Ei})^{2}}{E i}$ \\
\hline $\begin{array}{c}\text { Tidak Obesitas } \\
\text { • Tidak } \\
\text { osteoartritis }\end{array}$ & 12 & 7.68 & 4.32 & 18.6624 & 2.43000 \\
• Osteoartritis & 12 & 16.32 & -4.32 & 18.6624 & 1.14353 \\
\hline $\begin{array}{c}\text { Obesitas } \\
\text { - Tidak }\end{array}$ & & & & \\
osteoartritis & 28 & 32.32 & -4.32 & 18.6624 & 0.57743 \\
\hline - Osteoartritis & 73 & 68.68 & 4.32 & 18.6624 & 0.27173 \\
\hline Jumlah & 125 & 125 & & & 4.422685 \\
\hline
\end{tabular}

$\mathrm{p}$-value $=0.035$

Koefisien kontingensi $=0.185$ dengan $\mathrm{p}$-value $=0.035$

Odds ratio $=2.607$

\section{Obesitas dengan osteoartritis}

Berdasarkan hasil pengujian pada Tabel 5.6 menunjukkan nilai Chi-Square untuk mengetahui adanya hubungan antara kejadian osteoartritis dengan obesitas menggunakan metode pengukuran BMI yaitu sebesar 4.423 yang lebih besar dari c2 tabel dengan $\mathrm{df}=1$, yaitu sebesar 3.841, dengan nilai signifikansi (p) sebesar 0.035 yang lebih kecil dari alpha 0.05. Sehingga dapat disimpulkan bahwa antara kejadian osteoartritis dengan obesitas menggunakan metode pengukuran BMI mempunyai hubungan yang signifikan (bermakna). Oleh karena tabel silang yang terbentuk adalah 2x2, maka juga digunakan pendekatan Fisher's Exact test yang menunjukkan nilai signifikansi (p) sebesar 0.045 yang juga lebih kecil dari alpha 0.05 , sehingga dapat disimpulkan bahwa antara kejadian osteoartritis dengan obesitas menggunakan metode pengukuran BMI mempunyai hubungan yang signifikan (bermakna). Selanjutnya dari hasil analisis juga diperoleh nilai Odds Ratio (OR) sebesar 2.607, artinya seseorang yang tergolong obesitas, beresiko 2.6 kali dapat terkena osteoartritis dengan persentase yang terbesar yaitu $58.4 \%$, daripada yang tidak tergolong obesitas.

Salah satu koefisien pengukur korelasi antar data berskala nominal (artinya kategori dari kejadian osteoartritis dengan obesitas merupakan data yang berskala nominal), yang digunakan dalam penelitian ini adalah koefisien korelasi kontingensi. Ukuran dari derajat keeratanhubungan antara kejadian osteoartritis dengan obesitas menggunakan metode pengukuran BMI, dapat diinterpretasikan sebagai berikut. Berdasarkan Tabel 2. menunjukkan nilai koefisien korelasi kontingensi untuk hubungan antara kejadian osteoartritis dengan obesitas menggunakan metode pengukuran BMI sebesar 0.185 dengan nilai signifikansi (p) sebesar 0.035 yang lebih kecil dari alpha 0.05 . Hal ini berarti hipotesa alternatif yang menyatakan adanya keeratan hubungan antara kejadian osteoartritis dengan obesitas menggunakan metode pengukuran BMI dapat diterima, dan menolak hipotesa nol (Ho). Dengan kata lain antara kejadian osteoartritis dengan obesitas menggunakan metode pengukuran BMI mempunyai keeratan hubungan yang signifikan (bermakna), dengan arah korelasi yang positif. Artinya, semakin tinggi hasil pengukuran BMI yang mengindikasikan tergolong obesitas, maka ia akan beresiko lebih tinggi terkena osteoartritis. Sebaliknya, semakin rendah hasil pengukuran BMI yang mengindikasikan tidak tergolong obesitas, maka ia akan beresiko lebih rendah terkena osteoartritis. Adanya kaitan erat antara hubungan antara kejadian osteoartritis dengan obesitas menggunakan metode pengukuran BMI dapat digambarkan dalam bentuk histogram sebagai berikut.

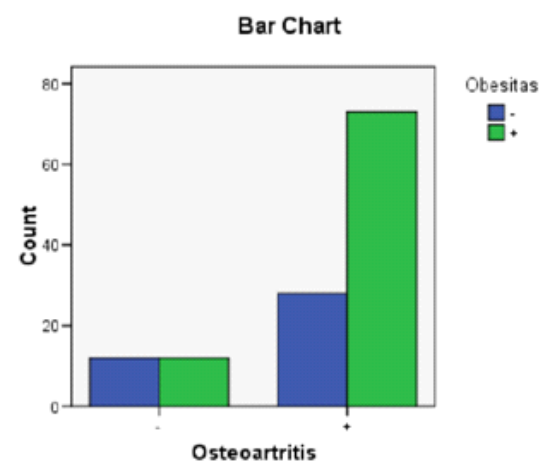

Gambar 6. Grafik Hubungan Antara Kejadian Osteoartritis Dengan Obesitas Menggunakan Metode Pengukuran BMI (Body Mass Index)

Berdasarkan Grafik 6 di atas dapat diketahui bahwa semakin tinggi hasil pengukuran BMI yang mengindikasikan tergolong obesitas, maka ia akan beresiko lebih tinggi terkena osteoartritis. Sebaliknya, semakin rendah hasil pengukuran BMI yang mengindikasikan tidaktergolong obesitas, maka ia akan beresiko lebih rendah terkena osteoartritis lebih positif daripada yang mempunyai pengetahuan kurang baik.

\section{PEMBAHASAN}

Berdasarkan hasil penelitian dari data rekam medik pasien yang menjalani rawat jalan yang melakukan pengobatan lanjutan atau kontrol kesehatan di bagian rheumatologi RS Swasta Kota Malang pada periode Januari - Desember 2006, didapatkan jumlah sampel yang mewakili populasi sebanyak 125 pasien. Penentuan jumlah sampel minimum dihitung dengan menggunakan rumus Slovin, didapatkan jumlah sampel minimum adalah 90 pasien.

Tehnik pengambilan sampel dilakukan secara acak dari populasi pasien bagianrheumatologi periode 2006 yang berjumlah 907 pasien. Didapatkan 125 pasien memenuhikriteria inklusi yang ditetapkan, yaitu pasien yang menderita osteoartritis baik yang obesitas maupun tidak dan dengan pasien yang tidak osteoartritis baik yang obesitas maupun tidak.

\section{Karakteristik penderita Osteoartritis Usia}

Tabel 4. Distribusi karakteristik Responden berdasarkan Usia

Distribusi Karakteristik Responden Berdasarkan Usia

\begin{tabular}{|c|c|c|}
\multicolumn{2}{|c|}{ Distribusi Karakteristik Responden Berdasarkan Usia } \\
\hline Usia (tahun) & Frekuensi & Persentase (\%) \\
\hline $40-45$ th & 21 & $16.8 \%$ \\
$46-50$ th & 23 & $18.4 \%$ \\
$51-55$ th & 37 & $29.6 \%$ \\
$56-60$ th & 44 & $35.2 \%$ \\
\hline Total & 125 & $100 \%$ \\
\hline
\end{tabular}

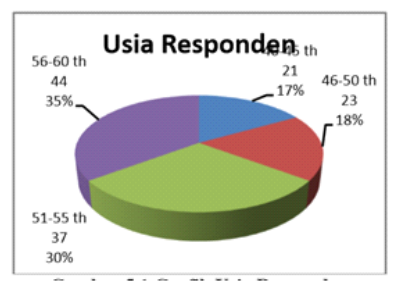

Gambar 7. Grafik Usia Responden

Pada tabel dan gambar di atas menunjukan data 
mengenai frekuensi pasien Osteoartritis yang menjalani rawat jalan berdasarkan usia, didapatkan penderita terbanyak pada usia 51-60 tahun (35.2\%). Data tersebut sesuai dengan literatur (Isbagio, 2002; Anonymous, 2007) telah disebutkan bahwa pasien osteoartritis umumnya menyerang pada usia $>40$ tahun, prevalensi dan beratnya OA semakin meningkat dengan bertambahnya umur. Alasan peneliti melakukan pembatasan usia maksimal adalah 60 tahun, bertujuan untuk mengurangi faktor perancu, sebab pada usia lebih dari 60 tahun (semakin tua usia pasien) kejadian komplikasi kronis semakin meningkat, sehingga dikhawatirkan osteoartritis oleh karena komplikasi bukan karena obesitas (Bambang Setiyohadi, dkk 1995).

\section{Jenis Kelamin}

Tabel 5. Distribusi Karakteristik responden berdasarkan jenis Kelamin

\begin{tabular}{|c|c|c|}
\hline Jenis kelamin & Frekuensi & Persentase (\%) \\
\hline Laki-laki & 37 & $29.6 \%$ \\
Perempuan & 88 & $70.4 \%$ \\
\hline Total & 125 & $100 \%$ \\
\hline
\end{tabular}

\section{Jenis Kelamin}

\section{Responden}

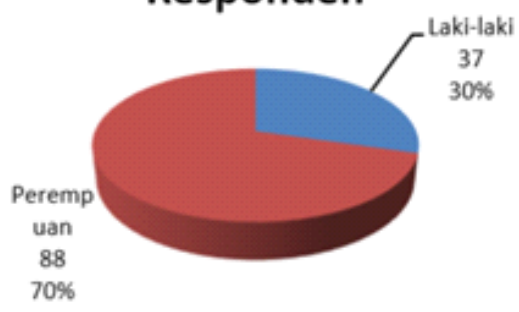

Gambar 8. Grafik Jenis kelamin Responden

Pada tabel dan gambar diatas menunjukan data mengenai frekuensi pasien rheumatologiyang menjalani rawat jalan berdasarkan jenis kelamin, didapatkan penderita osteoartritisterbanyak adalah perempuan yaitu $70.4 \%$. Data tersebut sesuai dengan literatur disebutkanbahwa frekuensi osteoartritis lebih banyak pada wanita disebabkan adanya peran hormonal yaituhormon estrogen (Soeroso dkk, 2006).

\section{Hasil analisa Uji Chi Square}

Berdasarkan hasil tabel silang menunjukkan bahwa semakin tinggi hasil pengukuran BMI yang mengindikasikan tergolong obesitas, maka ia akan beresiko lebih tinggi terkena osteoartritis. Sebaliknya, semakin rendah hasil pengukuran BMI yang mengindikasikan tidaktergolong obesitas, maka ia akan beresiko lebih rendah terkena osteoartritis. Dimana hal ini jugadidukung oleh hasil uji chi-Square (c2) sebagai test independency yang menunjukkan bahwaantara kejadian osteoartritis dengan obesitas menggunakan metode pengukuran BMI mempunyaihubungan yang signifikan (bermakna). Ini diperoleh dari hasil pengujian dengan uji Chi-Square menunjukkan nilai signifikansi(p) sebesar 0.035 yang lebih kecil dari alpha 0.05 , dengan korelasi yang positif $(r=0.185$ danp=0.035). Jadi, pasien yang tergolong obesitas mempunyai resiko yang lebih besar terkenaosteoartritis, daripada yang tidak tergolong obesitas karena mempunyai resiko yang lebih kecilterkena osteoartritis.
Hasil penelitian ini sesuai dengan apa yang diungkapkan oleh Soeroso dkk (2006),dimana disebutkan bahwa berat badan berlebih (obesitas) berkaitan dengan meningkatnya risikountuk timbulnya OA. Hal ini juga diperkuat dari literatur (Kashmirj. YI, 2007) disebutkanObesitas merupakan salah satu pendorong terjadinya osteoartritis (pengapuran sendi) yang bisa memunculkan rematik. Itu terjadi karena timbunan lemak di tubuh membebani persendianpanggul, pinggang, dan (terutama) lutut. Untuk itu, mereka yang kegemukan disarankan untuk lebih sering berolahraga agar mengurangi risiko terjadinya rematik.

\section{KESIMPULAN}

Berdasarkan hasil dan pembahasan dalam penelitian ini dapat ditarik kesimpulan sebagai berikut:

1. Berdasarkan hasil penelitian dapat diketahui bahwa prevalensi osteoartritis pada pasien bagian rheumatologi dengan indikasi obesitas adalah sebesar $58.4 \%$.

2. Melalui hasil uji chi-Square (c2) sebagai test independency menunjukkan bahwa antara kejadian osteoartritis dengan obesitas menggunakan metode pengukuran BMI mempunyai hubungan yang signifikan (bermakna) $(\mathrm{p}<0.05)$.

\section{DAFTAR PUSTAKA}

Anonymous. 2005. Ketika Jari Mulai Sakit. Semijurnal Farmasi \& Kedokteran. Ethical Digest No. 18 tahun III Agustus 2005. Jakarta

A. Kusumawardhani. 2006. Food Addiction in Obesity. Majalah kedokteran Indonesia. Volume: 56, hal. 205208

Anonymous. 2007 (http://www. medicastore. com)

Anonymous. 2004 (http://www.obesitas.web.id)

Arisman, DR. 2004. Gizi Dalam Daur Kehidupan. Jakarta : Penerbit Buku Kedokteran EGC. Hal: 98.

Basha, Adnil. 2007. Management of Obesity in Cardiovascular Medicine. Jakarta

Behrman RE, Vaughan VC. 2000. Ilmu Kesehatan Anak: Nelson. Diterjemahkan

oleh: Moelia Radja Siregar. Jakarta: Penerbit Buku Kedokteran EGC. Hal : 303

Brandt, Kenneth D. 1995. Prinsip-Pinsip Ilmu Penyakit Dalam Harrison: Osteoartritis. Jakarta: EGC

Departemen Kesehatan R I. 2005 (http:/ /www.suarakaryaonline.com/news.html)

Hermawan, A. Guntur. 1991. Cermin Dunia Kedokteran: Komplikasi Obesitas dan Usaha Penanggulangannya. Surakarta

Irga. 2008. Patofisiologi Osteoartitis. (www.irwanashari/ osteoartritis.co.id)

Isbagio, Harry. 2002. Cermin Dunia Kedokteran: Struktur Rawan Sendi dan Perubahannya pada Osteoartritis. Jakarta

Isbagio, Harry. 2006. Buku Ajar Ilmu Penyakit Dalam Jilid II Edisi IV: Osteoartritis. Jakarta: Balai Penerbit FKUI xxvii 
Kalim, Handono. 2000. Buku Ajar Ilmu Penyakit Dalam Jilid III Edisi IV: Penyakit Sendi Degeneratif (Osteoartritis). Jakarta: Balai Penerbit FKUI

Kashmirj, Yoga Iwanoff. 2007. Rheumatic Diseases and the New Evidence on Cox 2 Selective Inhibitors: Kegemukan Berisiko Rematik. Balikpapan

Merdikoputro, Djoko. 2006. Mampu Menurunkan $100 \mathrm{Kg}$. Available from URL : www.suaramerdeka.com/harian/ kesehatan. Diakses 08 Agustus 2007

Padang, Cecilia R. 2001. Reumatik, Pengkapuran, dan Pengkeroposan Tulang : Setiap Orang Pasti Terkena Pengapuran. Jakarta

Pudjiadi, DSAK. 1997. Ilmu Gizi Klinis Pada Anak. Jakarta: Balai Penerbit FKUI. Hal : 144-147

Rini, Nisa Ike. 2007. Apakah Obesitas itu ?. Available from URL : www.pjnhk.go.id/content. Diakses 05 November 2007

Rubenstein, D., Wayne, D.,Bradley ,J. 2003. Lecture Notes Kedokteran Klinis. 6th ed. Jakarta: Erlangga. Hal: 212

Sastroasmoro, Sudigdo. 1995. Dasar-Dasar Metodologi Penelitian Klinis. Jakarta: Binarupa Aksara. Hal: 42

Sediaoetama, Achmad Djaeni. 2000. Ilmu Gizi Jilid 1. Jakarta : Penerbit Dian Rakyat. Hal : 25-29; 197-198; 235-240

Setiyohadi, Bambang, dkk. 2006. Masalah dan Penanganan Osteoartritis Sendi Lutut. Available from URL : www.kalbe.co.id/cerminduniakedokteran. Diakses 12 Agustus 2007

Soeroso, Joewono, dkk. 2006. Buku Ajar Ilmu Penyakit Dalam Jilid II Edisi IV: Osteoartritis. Jakarta: Balai Penerbit FKUI

Soetjiningsih. 1998. Tumbuh Kembang Anak. Jakarta: Penerbit Buku Kedokteran EGC. Hal : 1; 37-46; 89-90; 184-188 xxviii

Sudoyo, A.W., et al. 2006. Buku Ajar Ilmu Penyakit Dalam.Jilid 2, 4th ed. Jakarta.: Departemen Ilmu Penyakit Dalam FK UI. hlm. 1184-1191

Sugondo, Sidartawan. 2006. Buku Ajar Ilmu Penyakit Dalam Jilid III Edisi IV: Osteoartritis. Jakarta: Balai Penerbit FKUI

Staff Pengajar Ilmu Kesehatan Anak Fakultas Kedokteran Universitas Indonesia.1985. Ilmu Kesehatan Anak 1. Jakarta : Bagian Ilmu Kesehatan Anak Fakultas Kedokteran Universitas Indonesia. Hal : 147; 151-157; 366-367

Wed. 2004. Lebih dari Satu Miliar Penduduk Dunia Kelebihan Berat Badan dan Obesitas. Available from URL : www.gizi.net/cgi-bin. Diakses 30 Juli 2007

Wirakusumah. 1994. Cara Aman dan Efektif Menurunkan Berat Badan. Jakarta : Gramedia. Hal : 3-5

Witjaksono, Fiastuti. 2002. Obesitas Bukan Lagi Tanda Kemakmuran. Available from URL : www.kompas.com/inspirasi/kesehatan. Diakses 07 Oktober 2007

World Health Organization. 2003 (www.pdpersi.co.id/ ?show=detailnews) 